\title{
Ideas and Explanation in Early Modern Philosophy*
}

\author{
Kenneth L. Pearce \\ Trinity College Dublin
}

March 9, 2019

\begin{abstract}
Malebranche argues that ideas are representative beings existing in God. He defends this thesis by an inference to the best explanation of human perception. It is well known that Malebranche's theory of vision in God was forcefully rejected by philosophers such as Arnauld, Locke, and Berkeley. However, the notion that ideas exist in God was not the only controversial aspect of Malebranche's approach. Another controversy centered around Malebranche's view that ideas are to be understood as posits in an explanatory theory. Opponents of this approach, including Arnauld and Locke, held that our talk about ideas was not explanatory but instead merely descriptive: we use the word 'idea' to describe phenomena that we observe by reflecting on our own minds. This controversy has not received much attention from scholars, but in the present paper I will show that it was an explicit and important subject of concern for Malebranche, Arnuald, Locke, and Berkeley and that attention to this controversy can illuminate several aspects of these philosophers' work.
\end{abstract}

For the 17th and 18th century opponents of the 'New Philosophy', one of its most visible identifying features was "the talking of ideas, and running endless divisions upon them" (Browne 1697, 3; compare Stillingfleet 1697, 273; Sergeant 1697, Epistle Dedicatory). ${ }^{1}$ Since their use of the word 'idea' was new and controversial, it is surprising that most early modern philosophers say so little about what they take ideas to be and why we ought to believe in such things. Instead, we frequently find them beginning with remarks like this one from the 1662 Port-Royal Logic: "The word 'idea' is one of those that are so clear that they cannot be explained by others, because none is more clear and simple" (Logic, 25). ${ }^{2}$

One early modern philosopher who strikingly stands apart from this approach is Nicolas Malebranche. Malebranche is quite explicit about what ideas

${ }^{*}$ This is the author's accepted manuscript. The version of record will appear in Archiv für Geschichte der Philosophie.

1. For a history of opposition to the 'way of ideas' see Yolton 1956.

2. Thomas Reid ([1785] 2002, 174) remarks, "the authors who have treated of ideas, have generally taken their existence for granted, as a thing that could not be called in question." 
are and what reason we have to believe in them. According to Malebranche, ideas are representative beings in God. We are to believe in them on the basis of an inference to the best explanation. The fact to be explained is our ability to perceive external objects. The best explanation of this fact is that we perceive external objects because "the mind surely can see what in God represents created beings... provided that God wills to reveal to it what in Him represents them" (SAT, 230).

It is well known that Malebranche's theory of vision in God was forcefully rejected by philosophers such as Antoine Arnauld, John Locke, and George Berkeley. However, the notion that the ideas we perceive exist in God and not in our own minds was not the only controversial aspect of Malebranche's approach. Another controversy centered around Malebranche's view that ideas are to be understood as posits in an explanatory theory. Opponents of this approach, including Arnauld and Locke, held that our talk about ideas was not explanatory but instead merely descriptive: we use the word 'idea' to describe phenomena that we observe by reflecting on our own minds.

The dispute between explanatory and descriptive approaches is a methodological dispute about how to justify claims about the existence and nature of ideas. The explanatory approach justifies such claims by inference to the best explanation of some phenomena. The descriptive approach justifies such claims by direct observation. Malebranche is the most explicit early modern proponent of the explanatory approach. Arnauld and Locke, on the other hand, both endorse descriptivism. Despite deep differences in epistemology and in the metaphysics of perception, they both hold that claims about the existence and nature of ideas are to be justified by direct introspection.

Descriptivism about ideas, however, faces a serious difficulty. Each of us can inspect and describe only our own ideas. How, then, can a proponent of this methodology defend her claims against an opponent who claims to introspect something different? This difficulty is at the center of Berkeley's argument against abstract ideas.

The controversy between explanatory and descriptive understandings of ideas has not received much attention from scholars, but in the present paper I will show that it was an explicit and important subject of concern for many early modern philosophers. I will focus, in particular, on Malebranche, Arnauld, Locke, and Berkeley.

In $§ 1$ I provide a more detailed account of Malebranche's inference to the best explanation. In $\S 2$, I show that Arnauld does not merely argue that Malebranche's explanation fails but rather that the phenomenon in question (our ability to perceive external objects) does not stand in need of explanation in the first place. Arnauld's descriptivism is based on this rejection of the need for explanation. In $\S 3$, I examine Locke's attitude to the dispute between Malebranche and Arnauld. It has previously been claimed that Locke appears to position himself on the side of Arnauld, which is puzzling since Arnauld is a direct realist and it is difficult to reconcile any form of direct realism with Locke's text. I argue that Locke's agreement with Arnauld is not about the metaphysics of perception at all. Rather, Locke agrees with Arnauld's descriptivism. How- 
ever, whereas Arnauld's descriptivism was based on the claim that the relevant phenomena stood in no need of explanation, Locke's descriptivism is based on the claim that this sort of explanation is permanently beyond our reach. Finally, in $\S 4$, I argue that this background can help us to make sense of Berkeley's argument against abstract ideas: Berkeley's central contention is that talk of abstract ideas is not apt for describing what can be introspected. As a result, if abstract ideas are to be introduced, they must be introduced as posits of an explanatory theory. But such theories fail to explain the phenomena in question.

\section{Malebranche}

In The Search After Truth, Malebranche introduces his discussion of the nature of ideas as follows:

I think everyone agrees that we do not perceive objects external to us by themselves. We see the sun, the stars, and an infinity of objects external to us; and it is not likely that the soul should leave the body to stroll about the heavens, as it were, in order to behold all these objects. Thus, it does not see them by themselves, and our mind's immediate object when it sees the sun, for example, is not the sun, but something that is intimately joined to our soul, and this is what I call an idea (SAT, 217).

The basic datum, then, is that "We see... an infinity of objects external to us." The explanatory puzzle stems from the fact that these objects are not "intimately joined to our soul" in the way that would be necessary if they were to be immediate objects of thought. The much-ridiculed remark about 'strolling about the heavens' may perhaps be meant to suggest that the stars' distance from me is an impediment to their being 'intimately joined' to my soul, or it may merely be a rhetorical way of denying that such joining occurs. ${ }^{3}$

In the very next paragraph, Malebranche mentions some additional puzzles about perception:

it often happens that we perceive things that do not exist, and that even have never existed... When a madman or someone asleep or in a high fever sees some animal before his eyes, it is certain that what he sees is not nothing. . . though. . . the animal [has] never existed (217).

According to Malebranche "To see nothing is not to see; to think of nothing is not to think" (320). Hence, when the external object perceived is not intimately joined to the mind (and so is not immediately perceived), or even when the

3. Arnauld clearly understands the remark in the first way (TFI, ch. 4; see Ndiaye 1991, 116120), but in his response Malebranche appears to say that he intended it in something like the second way (Malebranche [1684] 1958-1978, 94-96). For further discussion of Malebranche's line of thought here, see Yolton 1984, 47-51, 65-66; Jolley 1990, 85-86; Nadler 1992, 67-79; Lennon 1992; Hight 2008, 61-64. 
object does not exist, there must be something we (immediately) perceive, and that something is the idea. ${ }^{4}$

There is, according to Malebranche, an even more puzzling phenomenon that must be explained, having to do not with sensory perception but with voluntary thought. Malebranche writes:

It is certain, and everyone knows from experience, that when we want to think about some particular thing, we first glance over all beings and then apply ourselves to the consideration of the object we wish to think about. Now, it is indubitable that we could desire to see a particular object only if we had already seen it, though in a general and confused fashion. As a result of this, given that we can desire to see all beings, now one, now another, it is certain that all beings are present to our mind (SAT, 232).

The problem here is a version of Plato's Paradox of Inquiry: "[a person] cannot search for what he knows - since he knows it, there is no need to searchnor for what he does not know, for he does not know what to look for" (Plato Meno 80e). In the case that concerns Malebranche, the paradox is perhaps even more troubling: how can one want or choose to think about (e.g.) horses if one is not already thinking about horses? Isn't such a desire or choice itself a thought about horses? ${ }^{5}$

According to Malebranche, there are just five possible explanations of these phenomena:

either (a) the ideas we have of bodies and of all other objects... come from these bodies or objects; or (b) our soul has the power of producing these ideas; or (c) God has produced them in us while creating the soul or produces them every time we think about a given object; or (d) the soul has in itself all the perfections it sees in bodies; or else (e) the soul is joined to a completely perfect being that contains all intelligible perfections, or all the ideas of created beings (SAT, 219).

Malebranche proceeds to examine these alternatives one by one, ultimately arriving at the conclusion: "I do not think there is any plausibility in any of the other ways of explaining these things, and this last way [vision in God] seems more plausible" $(235) .{ }^{6}$

A great deal more could be said regarding the details of Malebranche's vision in God, but for present purposes the key point is just this: Malebranche posits a class of entities, ideas, in order to explain how we can perceive things that are not 'intimately joined' to the soul and may not even exist. He then argues that, in order to do the necessary work, these ideas must be understood as

4. On this line of argument, see Nadler 1992, 79-92.

5. For further discussion of this argument, see Nadler 1992, 141-143.

6. For further discussion of this 'argument by elimination,' see McCracken 1983, 61-70; Nadler 1992, 108-140; Schmaltz 2000, 69-71; Pyle 2003, 50-57; Priarolo 2017, 145-149. 
parts or aspects of the divine essence. ${ }^{7}$ Thus Malebranche argues by inference to the best explanation that we see external objects by "see[ing] what in God represents created beings" (SAT, 230). These divine representations are what Malebranche calls 'ideas'.

\section{Arnauld}

The dispute between Malebranche and Arnauld about the nature of ideas was a major philosophical event in the late 17th century. The debate was notoriously heated, frequently involving personal attacks and disagreements about just what was at stake (Pyle 2003, 83-89). ${ }^{8}$ Arnauld characterizes the fundamental point of disagreement between himself and Malebranche as a disagreement over whether ideas are (as Malebranche thinks) 'representative beings' "actually distinct from our mind as well as from the [external] objects" (TFI, 63), or whether (as Arnauld thinks) "the idea of an object and the perception [i.e., act of perceiving] of that object [are] the same thing" (65). In other words, Malebranche's ideas are perceptual intermediaries standing between the mind and the (external) object, and Arnauld denies that there are any such perceptual intermediaries. Arnauld thus endorses a form of direct realism and Malebranche endorses a form of representationalism. ${ }^{9}$

In his first response to Arnauld's critique, Malebranche gives a very different account of the question at issue:

what is the issue at hand? Mr. Arnauld insists that the modalities of the soul are essentially representative of objects distinct from the soul; and I maintain that these modalities are nothing but sensations, which do not represent to the soul anything different from itself (Malebranche [1684] 1958-1978, 50; translation from Nadler 1989, $82)$.

Malebranche denies that any mode of the mind is 'essentially representative'

7. On Malebranche's argument for the claim that in order to play these explanatory roles ideas must be independent of our minds, see Nadler 1992, 34-44; Hight 2008, §§3.1-3.3.

In the Tenth Elucidation, Malebranche (drawing heavily on Aquinas) engages in some fancy footwork to try to reconcile his doctrine with divine simplicity (SAT, 624-626). For detailed discussion of the relationship between Malebranche's theory of ideas and the commitments of traditional philosophical theology, see Cook 1998; Pessin 2004; Priarolo 2017, 157-165.

8. For an overview of the dispute, see Moreau 2000. Walter Ott $(2017,155 n 44)$ exaggerates when he writes, "Only at isolated moments [in the Malebranche-Arnauld dispute] does one catch something worthwhile. On the whole reading these texts is a dismal experience, like reading unedited comments on a political blog." Nevertheless, the debate is certainly not a model of charity or mutual understanding in philosophical exchange.

9. It is widely held that Arnauld endorses some form of direct realism, though there is disagreement over the details. See Cook 1974, 1991; Radner 1976; Nadler 1989; Hight 2008, §3.5; Pearce 2016. Some scholars have questioned whether Arnauld really (consistently) endorses direct realism. See Hoffman 2002; Van Cleve 2015; Ott 2017, §6.4.

Steven Nadler (1992, 1994), revising his own previous view (Nadler 1989, ch. 3), has questioned the traditional interpretation of Malebranche as a representationalist. For criticism of Nadler's (new) interpretation on this point, see Pyle 2003, 71-73. 
and therefore denies that any mode of the mind could be an idea. Arnauld, on the other hand, takes our perceptual acts to be essentially representative of their objects (in a sense to be explained below).

Although Malebranche and Arnauld give different accounts of what their most important disagreement is, they do disagree on both of these issues. ${ }^{10}$ However, as Arnauld clearly saw, these disagreements are both manifestations of a deeper, methodological divide between them. Chapter one of On True and False Ideas therefore outlines Arnauld's philosophical method, enumerating seven rules. Of these, rules three and five are of central importance for us:

The third [rule] is not to seek reasons ad infinitum, but to stop when we get to what we know to be the nature of a thing, or what we know with certainty to be a quality of it. One must not ask why extension is divisible, for example, or why the mind is capable of thought, for it is the nature of extension to be divisible, and that of mind to think.

...

The fifth is not to confuse questions which must be answered by providing a formal cause with those which require an efficient cause, and not to ask for the formal cause of a formal cause - something that is the source of many errors - but only for its efficient cause. An example will help us make this clearer. If I am asked why this piece of lead is round, I can reply by giving the definition of roundness, i.e., by providing the formal cause. . But if one continues to ask how it comes about that the surface of the lead is as I have described it, how it comes about that it is not shaped as it would be if the lead were a cube, then a Peripatetic will seek another formal cause, saying that it is because the lead has received a quality called roundness which has been drawn from the depths of its matter in order to make it round, and that it does not have any other quality which would make it a cube. But good sense requires us to reply by providing an efficient cause, by saying that the exterior surface of this piece of lead is due to its having been melted down and thrown into a hollow mould whose concave surface made the lead's surface convex (TFI, 50-51, translation corrected).

The key notion here is the distinction between formal and efficient causation. The formal cause of the lead's roundness is what it is about the lead that makes it count as round. The efficient cause is the chain of events that resulted in the lead's having that feature. Arnauld's claim, in rules three and five, is that there are no formal causes of formal causes: when one reaches a formal cause, one has reached a kind of explanatory bedrock, and explanations must come to an end.

This is, however, only a kind of explanatory bedrock: another kind of explanatory enterprise can continue, namely, efficient causal explanation. Thus

10. Nadler 1989, 81-88 argues that, at least for Arnauld, these are in fact one and the same issue, since Arnauld assumes that all modifications of the mind must be its acts or operations, so that if an idea is a mode of the mind then it is an act of the mind, i.e., a perception. 
once one knows the nature of roundness, it is nonsensical to ask, further, for the nature of the nature of roundness, but one can very well still ask how it came about that a particular sample of lead possessed that particular nature, i.e., was round.

Chapter two of On True and False Ideas applies these considerations to the nature of the mind and its ideas. According to Arnauld, the mind is by nature a thinking substance, hence by his rules it is nonsensical to ask why the mind thinks (TFI, 52-53). Of course, the question why the mind thinks has an efficient causal interpretation, on which it is a question about why a mind (i.e., a thinking thing) exists, in which case it is perfectly legitimate. The question that is ruled out is, what is it about the mind that makes it count as thinking? What makes something a mind is that it thinks, so the question what makes a mind think is, according to Arnauld, nonsensical.

The same principles are applied by Arnauld to individual ideas. Arnauld adopts a Cartesian substance-mode ontology, explaining the difference between substances and modes as follows:

The changes which occur in simple substances do not cause them to be something different from what they are, but only to be in some other way than they were. And this must be what distinguishes substances from modes, or ways of being, which can also be called modifications. But true modifications cannot be conceived without conceiving of the substance of which they are the modifications; so if it is my nature to think, and I can think of different things without changing my nature, then these different thoughts can only be different modifications of the thinking which constitutes my nature (TFI, 53; also see Logic, 30-32).

Just as being round is a way of being extended, thinking about roundness is a way of thinking. Since thought is the nature of mind, every modification of the mind must be a different way of thinking. Further, these ways of thinking are representational: "just as it is clear that $I$ think, it is also clear that I think of something, i.e., that I know and perceive something. For that is what thought is essentially" (TFI, 53). Arnauld even argues that the differences between different modes of thought are exhausted by differences in representational content: "we are not aware of anything else in our soul's thoughts which can change... but the perception and knowledge of an object" (TFI, 54; for discussion see Nadler 1989, 165-170). Thus, by his rules, Arnauld concludes that "it is ridiculous to ask how it comes about that our mind perceives objects" and "as regards the formal cause of our perception of objects, there is no question to be asked" (TFI, 54, emphasis added). The formal causal question Arnauld here rejects as nonsensical is the question, 'what is it about this thought that makes it a thought of roundness?' Such a question is absurd, since it is the nature of a thought (idea) to have the representational content it does (Pyle 2003, 76-79). ${ }^{11}$

11. Paul Hoffman (2002) characterizes representationalism (indirect realism) as an attempt to answer one or both of the following explanatory challenges: (1) how is it possible that we 
These reflections, coming at the beginning of On True and False Ideas, form the foundation of Arnauld's critique of Malebranche. ${ }^{12}$ Arnauld's central complaint is that Malebranche is positing dubious entities in an attempt to explain what needs no explanation. ${ }^{13}$ Regarding his own use of the word 'idea', on the contrary, Arnauld writes: "I also take the idea of an object and the perception of that object to be the same thing. I leave to one side whether there are other things that can be called ideas. For it is certain that there are ideas in this sense, and that they are attributes or modifications of our mind" (TFI, 65). Since "thought or perception is essentially reflective upon itself... [so that] I do not think without knowing that I think" (71), I am constantly aware of my ideas in introspection: that is, I am always aware that I am thinking or perceiving, and there is nothing more to the existence of ideas than my thinking or perceiving. When I talk about ideas, in other words, I am merely talking about the thinking or perceiving of which I am reflectively aware.

To summarize, then, the doctrine of On True and False Ideas is that I am immediately, introspectively aware of my thinking, and it is the nature of thought to represent (be of or about) an object. When I am thinking of an object I can be said to have an idea of that object. To ask what it is about this thought that makes it be about that object is illegitimately asking after the formal cause of a formal cause. Thinking just is representational and there is nothing more to be said. Talk about ideas is merely a way of expressing the fact-observable in introspection - that we think about various different objects. This amounts to an argument from Cartesian metaphysical and epistemological premises for the methodological principle that claims about ideas are to be justified only by direct introspection, and not by inference to the best explanation.

perceive things as having properties other than those they have? and (2) how is it possible that we perceive things at a distance? The representationalist, Hoffman says, answers one or both of these questions by positing special objects in the mind and claiming that we perceive external objects by perceiving these. Hoffman then goes on to argue that Aquinas, Descartes, and Arnauld are in this sense all representationalists, not direct realists. In his discussion of Descartes and Arnauld, Hoffman identifies a third explanatory challenge which, he says, Arnauld's theory of ideas is meant to address. This is the question of "how a particular act of awareness gets a particular [external] object" (Hoffman 2002, 173). This entire line of interpretation is mistaken, since Arnauld disavows any attempt to answer these questions. Since Arnauld rejects the very questions that, according to Hoffman, representationalism is intended to answer, Arnauld cannot possibly be a representationalist in Hoffman's sense.

12. For further discussion of Arnauld's methodological rules and the role they play in the critique of Malebranche, see Kambouchner 1995, 168-173.

13. Andrew Pyle (2003, 84-85) remarks that Malebranche would have characterized Arnauld's approach to intentionality as "an implicit rejection of the demand for an explanation." I am arguing that Arnauld's critique of Malebranche in fact involves an explicit rejection of this demand, and an argument for the claim that the demand is misplaced. 


\section{Locke}

Locke was certainly familiar with Arnauld's writings. ${ }^{14}$ Further, Locke commented extensively on the theory of ideas in Malebranche and Malebranche's English disciple, John Norris. These comments are generally critical. John Yolton $(1975,159-161)$ has suggested that many of Locke's criticisms are borrowed from Arnauld and has used this (alleged) similarity to support his claim that Locke, like Arnauld, was a direct realist (also see Yolton 1984, ch. 5).

Though much discussed, Yolton's interpretation has not gained wide acceptance. In general, scholars have found it simply too difficult to render Locke's text consistent with direct realism. ${ }^{15}$ For instance, Locke writes that the mind knows external objects "only by the intervention of the Ideas it has of them" (EHU, §4.4.3). Like Malebranche, Locke usually treats ideas as "immediate object $[\mathrm{s}]$ of Perception, Thought, or Understanding" (§2.8.8) which stand between the mind and the external object. In the Stillingfleet correspondence Locke explicitly rejects John Sergeant's view that "as often as your think of your cathedral church... the very cathedral church at Worcester... exists in your understanding" (LW, 4:390) and defines ideas as "immediate objects in [one's] mind, which are not the very things themselves" (4:391). Further, unlike Arnauld (TFI, ch. 6), Locke never gives any guidance as to how these modes of expression could possibly be rendered consistent with direct realism.

To what extent, then, do Locke's criticisms of Malebranche serve to align him with Arnauld? I suggest that, despite deep disagreement on epistemology and on the metaphysics of perception, Locke and Arnauld can be seen as agreeing in attacking Malebranche's inference to the best explanation in order to set up a purely descriptive methodology for the philosophy of ideas. ${ }^{16}$ In this section, I will first provide a textual and contextual defence of my claim that the account of ideas in the Essay is intended to be merely descriptive and not explanatory, then I will show that this observation allows us to make sense of Locke's remarks on Malebranche and Norris without attributing direct realism to Locke.

As is by now well-known, Locke intentionally sets the Essay in the context of Baconian natural history, the scientific enterprise of the Royal Society (Yolton 1996, 80-81; Rogers 2004, 2007; Allen 2010). ${ }^{17}$ This can be seen in Locke's mention of several prominent members of the Society in the Epistle to the Reader, and his description of his own role as that of an "Under-Labourer... removing some of the Rubbish, that lies in the way of Knowledge" (EHU, 10). It can also be seen in Locke's explicit description of his project as following the "His-

14. Locke's library at the time of his death included the first (1683) edition of TFI, as well as a French edition and a Latin translation of Logic, both dated 1674 (Harrison and Laslett 1971, 75).

15. Against direct realist interpretations see McCracken 1983, 132-133; Ayers 1991, vol. 1, chs. 6-7; Hight 2001, 17-24; 2008, §4.1; Yaffe 2004; Newman 2004, 2009; Bolton 2004; Pyle 2013, 33-36.

16. Descriptivism, in a sense very similar to mine, is also attributed to Locke by Ayers 1991, $1: 17-18$.

17. For a detailed account of Locke's own understanding and practice of Baconian natural history outside the Essay, see Anstey 2011. 
torical, plain Method" (EHU, §1.1.2), and in his assertion to Stillingfleet that "if [his 'way of ideas'] be new, it is but a new history of an old thing [i.e., human understanding]" (LW, 4:134-135). Further, it is clear that the Essay was received as a contribution to Baconian natural history in the decades following its publication. For instance, in a footnote to his 1732 translation of William King's Essay on the Origin of Evil, Edmund Law refers to the Essay concerning Human Understanding as "Mr. Locke's excellent History of the human mind" (Law 1732, 2:308), and in his 1734 Philosophical Letters, Voltaire writes, "After so many thinkers had written the romance of the soul, there came a wise man [Locke] who modestly described its history" (Voltaire [1734] 2007, 42). ${ }^{18}$

The project of Baconian natural history was derived from that of the ancient 'empiric' school of physicians. These physicians eschewed grand theories of the functioning of the human body or the causes of disease and focused instead on compiling detailed case histories. The aim was to repeat what works and avoid what doesn't, without seeking deep theoretical understanding (Hankinson 1987). ${ }^{19}$

In the same way, the natural historians of the Royal Society, following the program outlined by Bacon ([1620] 2000), sought to compile careful collections of 'instances' of observed natural phenomena and draw cautious generalizations from these. Although they were not perhaps so strict in avoiding theorizing as the empiric physicians, they thought it very important to avoid premature or over-ambitious theorizing. We must be particularly cautious to avoid allowing theory to pollute our observations. Thus Thomas Sprat describes the aims and methods of the Royal Society as follows:

The Society has reduc'd its principal observations, into one commonstock; and laid them up in publique Registers, to be nakedly transmitted to the next Generation of Men; and so from them, to their Successors. And as their purpose was, to heap up a mixt Mass of Experiments, without digesting them into any perfect model: so to this end they confin'd themselves to no order of subjects; and whatever they have recorded they have done it, not as compleat Schemes of opinions, but as bare unfinish'd Histories... For it is certain, that a too sudden striving to reduce the Sciences, in their first beginnings, into Method, and Shape, and Beauty; has very much retarded their increase... By their fair, and equal, and submissive way of Registring nothing, but Histories, and Relations; they have left room for others, that shall succeed, to change, to augment, to approve, to contradict them, at their discretion (Sprat 1667, 115-116).

According to Sprat, it is crucial to the Royal Society's method that observa-

18. The Essay is also characterized as a 'history' of the mind in the 18th century novel Tristam Shandy by Laurence Sterne (Anstey 2009). On Locke's Essay as a natural history of the understanding, also see Tomida 2005; Anstey 2009, §3; 2011, 223-225.

19. Locke himself authored two unfinished treatises advocating this approach to medicine. The manuscripts are dated 1668 and 1669, respectively, placing them two decades before the completion of the Essay (Anstey and Burrows 2009). 
tions be transmitted 'nakedly' in a 'mixt mass' and not interpreted or worked into a system (see Rogers 2007, 19-20). This separation of data from theory is crucial because it will enable future natural philosophers to question the conclusions being drawn from the evidence. Thus the Royal Society's registers contain 'bare unfinish'd Histories' rather than 'compleat Schemes of opinions'.

Similarly, Robert Hooke says that the Royal Society's most important rule is "that of avoiding Dogmatizing, and the espousal of any Hypothesis not sufficiently grounded and confirm'd by Experiments" (Hooke 1667, Dedication to the Royal Society). This of course implies that hypotheses are not to be rejected entirely; they are to be accepted to the extent that they are "sufficiently grounded and confirmed by experiments." However, this experimental confirmation can only go so far. Thus Hooke disavows any attempt to produce "infallible Deductions, or certainty of Axioms," instead contenting himself with "doubtful Problems, and uncertain ghesses." In gathering the data that makes up these hypotheses, the understanding "must watch the irregularities of the Senses, but it must not go before them, or prevent their information." This method, Hooke says, has been adopted by the Royal Society because "the Members of the Assembly having before their eys so many fatal Instances of the errors and falshoods, in which the greatest part of mankind has so long wandred, because they rely'd upon the strength of humane Reason alone, have begun anew to correct all Hypotheses by sense" (Preface). On Hooke's understanding of the Royal Society's Baconian project, we first amass the data by careful observation and only subsequently and tentatively offer hypotheses. These hypotheses are mere generalizations from what has been observed (compare Connolly 2018, §7). They do not involve the postulation of 'occult qualities' different in kind from immediately perceived qualities. ${ }^{20}$

This context makes excellent sense of the actual contents of Locke's Essay. In the introductory chapter of the Essay, Locke writes:

This, therefore, being my Purpose to enquire into the Original, Certainty, and Extent of humane knowledge; together, with the Grounds and Degrees of Belief, Opinion, and Assent; I shall not at present meddle with the Physical Consideration of the Mind; or trouble my self to examine, wherein its Essence consists, or by what Motions of our Spirits, or Alterations of our Bodies, we come to have any Sensation by our Organs, or any Ideas in our Understandings; and whether those Ideas do in their Formation, any, or all of them, depend on Matter, or no (EHU, §1.1.2).

After announcing that he will avoid theorizing about the essence or nature of mind and its relation to matter, Locke goes on to examine and catalogue various

20. Note that, as Robert Boyle ([1674] 1991, 142-144) convincingly argues, even the corpuscular hypothesis is in this sense merely an inductive generalization rather than an explanatory theory, for the corpuscular hypothesis merely extrapolates from our observations of the motion and interaction of macrophysical objects to claims about the motion and interaction of bodies too small for us to see. It does not posit any phenomena different in kind from those we directly observe. This is closely related to what Anstey (2011, 157-162) calls the 'Familiarity Condition' in Locke's account of empirical explanation. 
states of the mind. Thus the case against innate knowledge and innate ideas which occupies the remaining chapters of book one focuses primarily on arguing that no example of an innate idea or item of innate knowledge has yet been produced: there is no true specimen of such a thing in our register. Book two is then a detailed catalogue or register of ideas, and book four is a catalogue of instances of assent (knowledge and belief). ${ }^{21}$

In accord with this approach, Locke begins his natural history of ideas (book two) as follows:

Every Man being conscious to himself, That he thinks, and that which his Mind is employ'd about whilst thinking, being the Ideas, that are there, 'tis past doubt, that Men have in their Minds several Ideas (EHU, §2.1.1).

He goes on to remark that in defense of the various claims he will make in this book, he "shall appeal to every one's own Observation and Experience" (§2.1.1). The aim, in other words, is to describe and catalogue the ideas observed in introspection in order to draw inductive generalizations about ideas.

In his correspondence with Stillingfleet, Locke confirms that this was his approach in the Essay, and rejects Stillingfleet's claim that the Essay teaches a new way of reasoning or achieving certainty. Locke writes:

my design being, as well as I could, to copy nature, and to give an account of the operations of the mind in thinking, I could look into nobody's understanding but my own, to see how it wrought... All therefore that I can say of my book is, that it is a copy of my own mind, in its several ways of operation. And all that I can say for the publishing of it is, that I think the intellectual faculties are made, and operate alike in most men (LW, 4:138-139).

The aim of the Essay was not to teach a new method of reasoning, but to describe how "men have always performed the actions of thinking, reasoning, believing and knowing" (4:135).

If this account of Locke's approach in the Essay is correct, it places him firmly in the descriptivist camp: to suppose that Locke, like Malebranche, is introducing ideas as posits in an explanatory theory is to misunderstand the nature of his project and his Baconian methodology. Instead, like Arnauld, Locke takes it as epistemic bedrock that we have thoughts that are of or about things, and when we are thinking about something we can be truly said to have an idea of that thing. Locke and Arnauld share both the negative methodological thesis that claims about ideas are not to be justified by inference to the best explanation and the positive methodological thesis that such claims are to be justified by direct introspection.

21. Locke indicates that book three, on language, was an afterthought, not fitting neatly into the 'method' he originally proposed (EHU, §2.23.19). For discussion see Pearce 2019, $89-90$. 
Bringing this point of disagreement with Malebranche into focus also helps us to make sense of Locke's comments on Malebranche and Norris. These comments are found in two sets of notes, both published posthumously: Remarks on Some of Mr. Norris's Books and An Examination of P. Malebranche's Opin$i_{o n}{ }^{22}$ In these texts we find quite explicit support for the interpretation so far developed.

Locke opens the Remarks with explicit criticism of the explanatory ambitions of Norris and Malebranche:

THERE are some, who think they have given an account of the nature of ideas, by telling us, "we see them in God," as if we understood, what ideas in the understanding of God are, better than when they are in our own understandings... For what the divine ideas are, we know as plainly, as we know what 1,2 , and 3 , is; and it is a satisfactory explanation of what our ideas are to tell us, they are no other than the divine ideas; and the divine essence is more familiar, and level to our knowledge, than any thing we think of. Besides, there can be no difficulty in understanding how the "divine ideas are God's essence" (Locke [1706b] 1823, §1). ${ }^{23}$

This passage clearly drips with sarcasm, and it clearly aims in part to insinuate that Malebranche and Norris are guilty of the theological error of "enthusiasm', claiming a mystical insight into God's mind in a way that would violate divine transcendence. ${ }^{24}$ However, the passage also sets up Locke's most fundamental difference from Malebranche and Norris, which is a difference in their basic aims. As Locke explains in the next paragraph:

I am complained of [by Norris] for not having "given an account of, or defined the nature of our ideas". By "giving an account of the nature of ideas," is not meant, that I should make known to men their ideas; for I think nobody can imagine that any articulate sounds of mine, or any body else, can make known to another what his ideas, that is, what his perceptions are, better than what he himself knows and perceives them to be; which is enough for affirmations, or negations about them. By the "nature of ideas," therefore, is meant here their causes and manner of production in the mind, i.e. in what alteration of the mind this perception consists; and as to that, I answer, no man can tell $(\S 2)$.

Here, Locke clearly distinguishes his own project from that of Malebranche and Norris. Locke's 'affirmations or negations' about ideas are based solely on

22. On the history of the composition and publication of these texts, see McCracken 1983, 119-122.

23. In quoting both the Remarks and the Examination, I omit Locke's footnotes, most of which are citations to Malebranche and Norris.

24. On the extent to which Locke's critique of enthusiasm may be directed at Malebranche, see Lennon 1993, §11; Jolley 2003; 2007, §3. Berkeley also quite explicitly accuses Malebranche of enthusiasm (DHP, 214 [1734 ed.]). 
introspection. The kind of account of the nature of ideas Norris demands is, however, something else. As Locke puts it, Norris demands to know the "causes and manner of production [of ideas] in the mind."

Although Locke does not distinguish between efficient and formal causes here, he clearly has in mind the formal cause: the question is not what chain of events leads to the perception but rather "in what alteration of the mind this perception consists." Locke further clarifies:

what difference a man finds in himself, when he sees a marygold, and sees not a marygold, has no difficulty, and needs not be inquired after: he has the idea now, which he had not before. The difficulty is, what alteration is made in his mind, what changes that has in itself, when it sees what it did not see before (Locke [1706b] 1823, $\S 2)$.

The question, again, is the formal causal question, what is it about this mind that makes it count as seeing a marigold? Locke openly admits that in his Essay he made no attempt to answer this question. It is part of the "Physical Consideration of the Mind" Locke said he would avoid (EHU, §1.1.2).

Against Norris's (and Malebranche's) attempt to answer this question, Locke launches a two-pronged attack. First, on the assumption (endorsed by Malebranche and Norris) that the mind is a simple, immaterial substance, it is impossible to answer this question: "no man can give any account of any alteration made in any simple substance whatsoever; all the alteration we can conceive being only of the alteration of compounded substances; and that only by a transposition of parts" (Locke [1706b] 1823, §2). Second, the doctrine of vision in God cannot possibly be construed as an answer to this question. It does not matter whether one sees "the divine idea in the understanding of God, or, as the ignorant think, the marygold in the garden... for they are both things extrinsical to the mind, till it has that perception; and when it has it, I desire them to explain to me, what the alteration in the mind is" (§2).

The account of Locke's disagreement with Malebranche found in the Examination is quite similar. Locke begins by noting that:

P. Malebranche having enumerated, and in the following chapters showed the difficulties of the other ways, whereby he thinks human understanding may be attempted to be explained... erects this of 'seeing all things in God' upon their ruin, as the true, because it is impossible to find a better (Locke [1706a] 1823, §2).

As we have seen, this is an accurate account of Malebranche's procedure. Locke is quite explicit in rejecting this approach:

[This] argument, so far being only "argumentum ad ignorantiam," loses all its force as soon as we consider the weakness of our minds, and the narrowness of our capacities, and have but humility to allow, that there may be many things which we cannot fully comprehend $(\S 2)$. 
Locke goes on to complain that "it will very little help to cure my ignorance, that this is the best of four or five hypotheses proposed, which are all defective, if this too has in it what is inconsistent with itself, or unintelligible to me" (Locke [1706a] 1823, §2).

In Locke's view, to say that the doctrine of vision in God must be true because it is the only way we can explain perception is to assume "that God cannot make creatures operate, but in ways conceivable to us" (§8). According to Locke, this assumption is highly dubious. Indeed, it is Locke's view that no intelligible explanation of perception has ever been proposed, and probably no intelligible explanation ever will be proposed. In defense of this view, Locke goes on to argue (as he had in the Remarks) that vision in God does not provide an intelligible explanation of perception.

Throughout the Examination, Locke clearly favors mechanical explanations of perception, but he also clearly recognizes the limits of such explanations. Thus he writes:

if I should say, that it is possible God has made our souls so, and so united them to our bodies, that, upon certain motions made in our bodies by external objects, the soul should have such or such perceptions or ideas, though in a way inconceivable to us; this perhaps would appear as true and as instructive a proposition as [vision in God] ( $\S 8$, emphasis added).

Again, Locke suggests, "the perception we have of bodies at a distance from ours, may be accounted for, as far as we are capable of understanding it, by the motion of particles of matter coming from them and striking on our organs" $(\S 9)$. But this caveat, as far as we are capable of understanding it, is important. In the next section Locke confesses:

Impressions made on the retina by rays of light, I think I understand; and motions from thence continued to the brain may be conceived, and that these produce ideas in our minds, I am persuaded, but in a manner to me incomprehensible. This I can resolve only into the good pleasure of God, whose ways are past finding out... The ideas it is certain I have... but the manner how I come by them, how it is that I perceive, I confess I understand not (Locke [1706a] 1823, §10, emphasis added; compare EHU, §4.3.28).

This puzzle about the nexus between mind and body is not the only place where we find ourselves in a permanent state of ignorance, according to Locke. Similar puzzles loom when it comes to the nature of representation:

I shall here only take notice how inconceivable it is to me, that a spiritual, i.e. an unextended substance, should represent to the mind an extended figure, v.g. a triangle of unequal sides, or two triangles of different magnitudes. Next, supposing I could conceive an unextended substance to represent a figure, or be the idea of a figure, the difficulty still remains to conceive how my soul sees it (Locke [1706a] 1823, §18). 
According to Malebranche's representative theory of perception, the mind sees an external object by seeing an idea that represents it. There are two puzzles here: first, we must make sense of the notion of an idea representing an external object. Second, the mind's ability to see the idea must somehow be less puzzling or problematic than seeing the external object in the first place, or else no explanatory progress is made.

In stating the first puzzle, Locke emphasizes that the ideas in question are unextended. The worry here seems to be that we cannot understand how an unextended object could be like a picture of a triangle, and so it is difficult to understand how it could represent a triangle.

It is perhaps a bit surprising to find Locke raising this objection, for extension is a primary quality, and Locke is committed to the claim that ideas of primary qualities resemble their objects (EHU, §2.8.15). There has been considerable puzzlement about how to understand Locke's resemblance claim, ${ }^{25}$ but it seems that, no matter how we understand it, if ideas of extended objects can resemble those objects, then they can pictorially represent them.

This has led some scholars to suggest that Locke endorsed, or at least seriously considered, the view that (at least some) ideas should be identified with brain traces (e.g., Lennon 1993, ch. 5; Jacovides 1999). ${ }^{26}$ That may be so, but it is not Locke's central point in this passage. ${ }^{27}$ The central point is, again, that it is a manifest fact that we perceive (have ideas of) bodies, and yet this fact is deeply unintelligible to us. Malebranche's doctrine does nothing to make it more intelligible, since we do not understand how Malebranche's ideas could represent. Since Locke thinks this unintelligibility is unavoidable on any account, we should not assume that Locke means to rule out all of the claims he describes as unintelligible: it may well be that our ideas are immaterial and yet somehow extended, or it may be that our unextended ideas somehow resemble triangles in respect of their triangularity. ${ }^{28}$ Neither of these alternatives is intelligible to us, but neither is anything else we might possibly say about the matter. What Locke really wants to do, then, is not to rule out these claims

25. See, e.g., Curley 1972; Jacovides 1999; 2007, 106-108; 2017, ch. 8; Allen 2008, §3; Ayers 2011, 52-55; McCann 2011, 175-179.

26. Ayers (1991, vol. 1, ch. 5) argues on rather different grounds that Locke was agnostic about whether ideas were brain traces.

27. Jacovides $(1999,478)$ agrees that Locke does not take inconceivability to entail impossibility and that Locke's ultimate position on the corporeality of ideas is agnostic. Nevertheless, he takes this passage from the Examination as evidence that Locke took the possibility of corporeal ideas seriously.

28. It is unclear whether Locke's deep agnosticism here is fully consistent with his own account of intuitive knowledge, since the unintelligibility of this alleged connection might well be taken to amount to a "perception of the. . . disagreement and repugnancy of... Ideas" (EHU, $\S 4.1 .2)$. This concern forms the basis of Mary Astell's argument that Locke was mistaken in supposing that his theory allowed for the possibility of thinking matter (Astell [1705] 2013, $\S \S 386-393)$. Locke would presumably respond that failing to understand how there could be a connection is not the same as perceiving a 'repugnancy', but it is unclear how Locke can defend the claim that we do not perceive a repugnancy here, since, as Astell points out (§390), Locke must allow that we perceive a repugnancy between the ideas of sphere and cube although one is not the negation of the other. On Astell's argument see Squadrito 1987; Broad $2015, \S 4.1$. 
but to remain neutral, refraining from extending the understanding beyond its due bounds (compare McCracken 1983, 130-131; Allen 2010, §4).

Similar remarks apply to the second puzzle. As we have seen, Malebranche says that we can see ideas in God because the soul is intimately united to God. Locke replies: "Intimate union, were it as intelligible of two unextended substances as of two bodies, would not yet reach perception, which is something beyond union" (Locke [1706a] 1823, §18). Again, Malebranche's theory does nothing to make perception more intelligible.

Locke correctly regards Malebranche's account of ideas as a hypothesis designed to explain certain data. According to Locke, the key datum in question (our ability to perceive external objects) is permanently inexplicable to us, and the theory of vision in God has done nothing to make it any more intelligible. Locke, for his part, disavows this kind of explanatory theorizing and settles instead for inductive generalizations based on the ideas we directly introspect.

We are now in a position to see that, although Locke does to some extent follow Arnauld in his criticisms of Malebranche, there are also some important differences between them. These differences stem from their fundamentally different epistemological orientations. Arnauld, as a good Cartesian, holds that the epistemological bedrock consists of 'true and immutable natures' grasped by the pure intellect. It is this view that enables him to argue that Malebranche's question - asking for the formal cause of a formal cause -is illegitimate. Locke makes no such argument. According to Locke, Malebranche's question is perfectly legitimate but, like a great many perfectly legitimate questions, it is unanswerable by us. Thus Arnauld's descriptivism is born of a kind of primitivism and dogmatism: in Arnauld's view, the phenomena Malebranche seeks to explain have no explanations because they stand at the foundation of the order of knowledge which mirrors the order of being. That the mind perceives objects is simply a fundamental fact, constituting the very nature of the mind. Locke's descriptivism, on the other hand, is born out of a kind of skepticism: we should not attempt to engage in the kind of explanatory enterprise Malebranche attempts because this kind of enterprise is simply beyond the reach of our capacities. The best we can do is to describe and cautiously generalize from what we observe in introspection. ${ }^{29}$ Nevertheless, Locke and Arnauld endorse essentially the same methodology for the philosophy of ideas, a methodology that restricts itself to describing what we introspect. ${ }^{30}$

29. Allen 2010, 253 arrives at a similar conclusion regarding the relationship between Locke and Arnauld.

30. An anonymous referee suggests that Arnauld's view that the nature of mind and ideas are grasped by the pure intellect is inconsistent with descriptivism. However, in the first place, Cartesian true and immutable natures are not explanatory posits like Malebranche's ideas, but rather items directly grasped by the mind. Hence, although they are not experienced in the same way as ideas, we do have the kind of direct epistemic access that allows us to describe, rather than merely infer, them. In the second place, although Arnauld's claims about the nature of the mind and its ideas in general are meant to be justified a priori through the activity of the pure intellect, his claims about what particular ideas we humans have and how we employ them are justified through introspection. It is with respect to these particular claims that Arnauld's method is the same as Locke's. 


\section{Berkeley}

We have so far seen that Malebranche's theory of ideas - the doctrine of vision in God - is a genuine theory, supported on the basis of an inference to the best explanation. This inference was criticized by Arnauld and Locke who, each in different ways, rejected Malebranche's explanatory enterprise. Arnauld endorsed a form of primitivism, holding that the phenomena stood in no need of explanation; Locke endorsed a form of skepticism (or epistemic humility), holding that the phenomena could not be explained by us. Thus, in their discussions of ideas, both Arnauld and Locke disavowed any claim to explain how perception works, or how ideas represent objects. Instead, their talk of ideas is merely intended to describe what we introspect.

This historical context proves illuminating as to the dialectic of Berkeley's case against abstract ideas in the Introduction to his Treatise concerning the Principles of Human Knowledge. Ian Hacking once commented, "When you read Berkeley's Introduction, you should be struck by a surprising absence. Berkeley never argues that there are no abstract ideas!" (Hacking 1974, 39) This is an exaggeration, but it is nonetheless puzzling that the Introduction contains so little explicit argument for the impossibility of abstract ideas. What is even more puzzling is that the manuscript version contains much more explicit arguments on this point and Berkeley, for some reason, deleted these arguments. ${ }^{31}$ However, when Berkeley is seen as responding to the prior history we have outlined, the strategy pursued in the attack on abstract ideas becomes intelligible.

Berkeley, like Arnauld and Locke, adopts a descriptivist methodology in the philosophy of ideas. That is, he holds that claims about the existence and nature of ideas are to be justified by direct introspection. At the end of the published Introduction, Berkeley writes:

The objects I consider [i.e., my ideas], I clearly and adequately know. I cannot be deceived in thinking I have an idea which I have not. It is not possible for me to imagine, that any of my own ideas are alike or unlike that are not truly so. To discern the agreements or disagreements there are between my ideas, to see what ideas are included in any compound ideas, and what not, there is nothing more requisite than an attentive perception of what passes in my own understanding (PHK, Intro §22).

Similarly, in the body of the Principles, Berkeley writes:

To be satisfied [that there is nothing active in our ideas], there is nothing else requisite but a bare observation of our ideas. For since they and every part of them exist only in the mind, it follows that there is nothing in them but what is perceived $(\S 25)$.

31. For discussion of the arguments for the impossibility of abstract ideas, with attention to the differences between the manuscript and published versions, see Pearce 2017, 22-27. 
Finally, in the late work Alciphron, the character Euphranor (speaking for Berkeley) claims that, by reflection, "every one might easily know for himself whether he has this or that idea or no" (Alc, $\S 7.6$ [1732 ed.]).

However, the descriptivist approach faces a difficulty, which Locke had explicitly recognized in a comment to Stillingfleet which was quoted above: Locke "could look into nobody's understanding but [his] own," and the intersubjective validity of his results therefore depends on the undefended assumption that "the intellectual faculties are made, and operate alike in most men" (LW, 4:138-139). Suppose, then, that someone else claims to find different introspective results. As long as each person appeals to her own private mental states, they reach a dialectical impasse. Is there a way forward?

In fact, it is just this concern that explains the quotation from Port-Royal with which we began. Arnauld and Nicole's chapter "Ideas according to their nature and origin" begins by declaring the word 'idea' to be indefinable (Logic, 25 ), and yet the authors spend five pages clarifying what they mean by 'idea'! The point of this discussion is to ensure that the reader has performed the correct introspection, identifying the correct objects which are to be associated with the word 'idea'. This is something like the way we might take pains to ensure that someone is looking at the correct paint swatch to know what we mean by 'royal blue'. Thus, for instance, Arnauld and Nicole, adapting a wellknown example from Descartes ([1641] 1984-1991, 50-51), claim that we can have different ideas of a 1000-sided polygon and a 999-sided polygon, despite the fact that if we attempt to picture these shapes in the mind we will form the same image (Logic, 26). This observation is meant to assist us in introspectively distinguishing ideas from images.

What, though, if after all this care in identifying the correct introspective task, the interlocutor still disagrees? Arnauld and Nicole consider the case of Thomas Hobbes who, in the Third Objections to Descartes's Mediations, denies that he has an idea of God (Descartes [1641] 1984-1991, 127). Arnauld and Nicole write, "if we had no idea of God, in uttering the name 'God' we would conceive only these three letters, 'G,' 'o,' 'd."'32 On this hypothesis, Arnauld and Nicole argue, we would be unable to explain a number of phenomena:

a Frenchman would have nothing more in his mind on hearing the name Dieu than when, in entering a synagogue and being entirely ignorant of Hebrew, he heard Adonai or Elohim uttered in Hebrew.

Moreover, when men such as Caligula and Domitian called themselves God, they would not have committed any impiety since there is nothing in these letters or the two syllables Deus which could not be attributed to a man if no idea were connected to them.

...

If we had no idea of God, on what could we base everything we say about God, such as that there is only one, that he is eternal, all powerful, all good, all wise? None of this is contained in the sound "God," but only in the idea of God connected to this sound.

32. The original French of course employs the four letter French word 'Dieu' in the example. 
This is also the reason we refuse to give the name "God" to all the false divinities. It is... because the idea of a sovereign being connected by usage to this word "God" conforms only to the one true God (Logic, 27).

This passage contains a mixture of descriptive and explanatory elements. Arnauld and Nicole certainly believe that they can introspect the idea of God, and they hope that, given the proper instructions the reader will do the same by, e.g., focusing on what passes in her mind when she hears the word 'God' and how this is different from what occurs when she hears a word in a language she does not understand. However, Arnauld and Nicole also believe that they can silence Hobbes by pointing out the inexplicability of several linguistic phenomena on his view.

In introducing his discussion of ideas in book two, Locke likewise appeals to language to show that we possess ideas: "tis past doubt, that Men have in their Minds several Ideas, such as those expressed by the words, Whiteness, Hardness, Sweetness, Thinking, Motion, Man, Elephant, Army, Drunkenness, and others" (EHU, §2.1.1). Further, in introducing the doctrine of abstraction, Locke explicitly appeals to language:

The use of Words then being to stand as outward Marks of our internal Ideas, and those Ideas being taken from particular things... the Mind makes the particular Ideas, received from particular Objects, to become general... This is called ABSTRACTION, whereby Ideas taken from particular Beings, become general Representatives of all of the same kind; and their Names general Names, applicable to whatever exists conformable to such abstract Ideas (§2.11.9).

Locke goes on to appeal to (lack of) language as evidence that 'brutes' lack the faculty of abstraction: "This, I think, I may be positive in, That the power of Abstracting is not at all in [brutes]... since they have no use of Words, or any other general Sign" (§2.11.10). Thus not only does Locke take the meaningful use of general words to require the possession of abstract general ideas, he even takes the lack of general words as evidence for the lack of abstract general ideas.

In addition to these two passages in the Essay, Locke's Examination considers Malebranche's claim that we have no idea of an angel. Locke writes:

when [Malebranche] says we know not angels, either "in themselves or by their ideas, or by consciousness," what in that place does angel signify? What idea in him does it stand for? Or is it the sign of no idea at all, and so a bare sound without signification? (Locke [1706a] 1823, §50)

Locke does believe that he can introspect all of these ideas and that, given the correct instructions, his readers will be able to as well. But, again, in the face of an opponent (Malebranche) stubbornly claiming that his introspective results don't match Locke's, Locke appeals to an explanatory theory in the philosophy of language.

Berkeley is faithfully representing his predecessors when he writes: 
it is a received opinion that language has no other end but the communicating our ideas, and that every significant name stands for an idea. This being so, and it being withal certain that names, which yet are not thought altogether insignificant, do not always mark out particular conceivable ideas, it is straightway concluded that they stand for abstract notions (PHK, Intro §19).

Although both Port-Royal and Locke purport to base their claims about ideas on introspection, both also use this pattern of argument against recalcitrant opponents (compare Pearce 2017, 12-15). This strategy does not contradict or compromise the descriptivism of Port-Royal and Locke. Rather, it is a sort of backup argument: if the opponent won't admit that she can introspect the relevant ideas, perhaps she can nonetheless be made to admit their existence on account of the phenomena they explain. Similarly, if someone stubbornly denied that there was a cat in the house, one might respond: " $I$ believe in the cat because I'm looking right at it, but if you persist in denying its existence, then riddle me this: why does the cat food left in the dish keep disappearing?!" To adopt this strategy is certainly not to make the cat into some kind of theoretical posit. This is the kind of response Port-Royal and Locke offer to idea-deniers like Hobbes and Malebranche.

Berkeley's argument against abstract ideas represents a kind of inversion of this strategy, aimed at showing the absence, rather than presence, of ideas. Berkeley insists that he cannot introspect abstract ideas (PHK, Intro §10; DHP, 193-194; Alc, $\S 7.6$ [1732 ed.]). In a letter to the American Samuel Johnson, Berkeley is quite explicit that this is his reason for rejecting abstract ideas: "Mr. Locke... holds an abstract idea of existence... I cannot find that I have any such idea, and this is my reason against it" (Hight 2013, 319). Further, Berkeley notes in the Manuscript Introduction, "the Incomprehensibleness of Abstract Ideas to [his own] Understanding. . . may pass for an Argument [against abstract ideas], since those Gentlemen [i.e., the abstractionists] do not pretend to any new Facultys distinct from those of Ordinary Men" (MI, §14, markings omitted).

Berkeley believes that his opponents "would upon looking narrowly into their own Thoughts, find they wanted [i.e., lacked] it [the faculty of abstraction] as much as [Berkeley]" (§11). ${ }^{33}$ Berkeley's main aim, therefore, is to direct his readers' introspection in the right direction. To this end, he carefully distinguishes abstraction properly so-called from the kind of "compounding and dividing" of ideas that he admits to be possible (PHK, Intro $\S 10$ ) and he warns the reader not to confuse ideas with words (Intro $\S \S 22-24)$. This latter point- that if there really were an abstract idea of triangle we would be able to think of that idea in separation from the word 'triangle'-receives extra emphasis in Berkeley's later works (Alc, §§7.4, 7.8; Berkeley [1734] 1992, §§36-37; [1735] 1948-1957, §48).

The core of Berkeley's case against abstract ideas is just the challenge to the reader to frame an abstract idea (see Pearce 2017, 16-22):

33. In the manuscript, this text has been crossed out. 
try if you can frame the idea of any figure, abstracted from all particularities of size, or even from other sensible qualities (DHP, 194).

Do but try now whether you can frame an idea of number in abstract exclusive of all signs, words, and things numbered (Alc, §7.8).

if the reader is minded to make a short work, he needs only at once to try whether, laying aside the words, he can frame in his mind the idea of an impossible [i.e., abstract] triangle; upon which trial the issue of this dispute may be fairly put (Berkeley [1735] 1948-1957, $\S 48)$.

As we have seen, however, these kinds of disagreements among descriptivists lead to a dialectical impasse: Arnauld, Locke, and Berkeley each make their own descriptive claims and each with equal justification extrapolates from his own case to that of others. How can the impasse be broken?

In light of Arnauld's response to Hobbes and Locke's response to Malebranche, Berkeley very reasonably anticipates a response that appeals to language. Thus even after admitting that he cannot introspect abstract ideas, Berkeley's character Alciphron finds it difficult to give them up since "this is the opinion of all thinking men who are agreed, the only use of words is to suggest ideas" (Alc, $\S 7.7$ [1732 ed.]) and hence the word 'triangle' cannot be used meaningfully without a corresponding abstract idea. To explain, then, the meaningful use of general words like 'triangle', we must accept abstract ideas.

As we saw above, this explanationist view is not the view in fact endorsed by Arnauld and Locke. Rather, it is the 'fallback position' to which they will be driven if Berkeley's claims about the introspective facts are accepted. ${ }^{34}$ Berkeley therefore offers an alternative explanation of the relevant phenomena (PHK, Intro $\S \S 11-12,14-16,18)$, and also argues that the theory of language that takes abstract ideas to be necessary to explain the meaningfulness of general words does not in fact make sense of the phenomena (PHK, Intro $\S \S 18,20$; see Pappas 2000, 69-73; Pearce 2017, 27-29). Berkeley concludes, "We have, I think, shown the impossibility of abstract ideas... and endeavoured to show that they are of no use for those ends to which they are thought necessary. And lastly, we have traced them to the source form whence they flow, which appears to be language" (PHK, Intro $\S 21) .35$

In concluding that the "source from whence [abstract ideas] flow" is language, Berkeley takes his analysis a step further, providing an error theory to explain why Arnauld and Locke thought they could introspect abstract ideas. Berkeley's error theory here can be seen as, in a certain way, inverting the error theory Arnauld and Nicole give to explain why some people believe ideas are images:

34. George Pappas (2000, 72) writes, "these explanationist arguments would be strengthened if Berkeley were to add that the points he has raised about language use and communication are the only reasons that have been proposed for positing abstract ideas. However, Berkeley does not make such a claim." On the contrary, in its historical context Berkeley's text is plausibly read as claiming, or at least implying, this very thing.

35. For detailed exposition of Berkeley's argument here, see Pearce 2017, chs. 1 and 2. 
we have been so accustomed to thinking only about corporeal things, whose images enter the brain by the senses, that the majority believe themselves unable to conceive something if they cannot imagine it, that is, represent it under a corporeal image (Logic, 25).

According to Arnauld and Nicole, our habit of only thinking of imaginable things, and imagining them while we think of them, leads to a failure to distinguish the (non-imagistic) idea from the image that always accompanies it. However, by the right course of meditation, we can see that genuine thought involves ideas of the pure intellect and that thought in the absence of images is possible. According to Berkeley, due to a false theory of language, we have become accustomed to assuming that words are always accompanied by ideas and we haven't bothered to look and see whether the ideas are really there. However, by the right course of meditation, we can "remov[e] the Veil of Words" (MI, §54) to discover that in many cases even of meaningful speech there is no idea behind the 'veil' at all: "he that knows names do not always stand for ideas, will spare himself the labour of looking for ideas, where there are none to be had" (PHK, Intro §24). Berkeley, then, accepts the same descriptivist methodology for the philosophy of ideas that was held by Arnauld and Locke. However, Berkeley believes that his illustrious predecessors have been ensnared by "the embarrass and delusion of words" (Intro §25) to such an extent as to 'describe' a class of ideas that could not possibly exist.

\section{Conclusion}

What are ideas, and why should we believe in such things? Malebranche, we have seen, argues that ideas are intrinsically representational entities existing in God and we should believe in them because they are required by our best theory of how the mind perceives external objects. Arnauld and Locke reject Malebranche's explanatory ambitions. Arnauld argues that the question how the mind perceives external objects is illegitimate since it is the nature of mind to think and it is the nature of thought to have an object. Locke argues that the question how the mind perceives external objects, though legitimate, is unanswerable by us: although perception of external objects is manifestly a real occurrence, it is deeply unintelligible to us. Both Arnauld and Locke claim that when they speak of ideas they are not speaking of posits of an explanatory theory but rather of items directly observable in introspection.

The descriptivism of Locke and Arnauld, however, has a serious problem. Since each philosophers can only observe his or her own mind, a dialectical impasse is reached as soon as an opponent disagrees with the philosopher's description. In responding to opponents who deny the existence of certain sorts of ideas, Locke and Arnauld both appeal to an idea-based theory of language, arguing that if the opponent did not really have the ideas he claims to lack, he would not be able to use certain words meaningfully.

One such opponent is Berkeley, who rejects abstract ideas, denying that they are accessible to him in introspection. Berkeley recognizes that opponents, such 
as Arnauld and Locke, ${ }^{36}$ appeal to the need to explain the phenomena of language as support for abstractionism. However, Berkeley argues that this appeal fails, since the theory of language endorsed by the abstractionists does not succeed in explaining the phenomena in question, and an alternative explanation that does not appeal to abstract ideas is available. ${ }^{37}$

\section{Abbreviations}

Alc Berkeley, George. (1732) 2010. Alciphron: or, the Minute Philosopher. In Berkeley's Alciphron: English Text and Essays in Interpretation, edited by Laurent Jaffro, Geneviéve Brykman, and Claire Schwartz, 17-274. Hildesheim: Georg Olms Verlag.

DHP Berkeley, George. (1713) 2008. Three Dialogues Between Hylas and Philonous. In Philosophical Writings, edited by Desmond M. Clarke, 151-242. Cambridge Texts in the History of Philosophy. Cambridge: Cambridge University Press. Cited by marginal numbers.

EHU Locke, John. (1690) 1975. An Essay Concerning Human Understanding. Edited by Peter H. Nidditch. Oxford: Oxford University Press.

Logic Arnauld, Antoine, and Pierre Nicole. (1662) 1996. Logic or the Art of Thinking: Containing besides common rules, several new observations appropriate for forming judgments. Edited and translated by Jill Vance Buroker. Cambridge Texts in the History of Philosophy. Cambridge: Cambridge University Press. French edition: La Logique ou L'Art de Penser. 2nd ed. Edited by Pierre Claire and François Girbal. Textes Philosophiques. Paris: J. Vrin, 2012.

LW Locke, John. 1823. The Works of John Locke. 10 vols. London: Thomas Tegg.

MI Berkeley, George. 1987. George Berkeley's Manuscript Introduction: An Editio Diplomatica. Edited by Bertil Belfrage. Oxford: Doxa.

PHK Berkeley, George. (1710) 2008. A Treatise Concerning the Principles of Human Knowledge. In Philosophical Writings, edited by Desmond M. Clarke, 67-149. Cambridge Texts in the History of Philosophy. Cambridge: Cambridge University Press.

36. Locke is the only abstractionist Berkeley explicitly references. However, Berkeley's distinction between the three types of mental operations - one of which may be called 'abstraction" "in one sense" and the other two of which "are the proper acceptations of abstraction" bears a striking resemblance to the discussion of three types of 'knowledge by parts' in the Port-Royal Logic (PHK, Intro §10; Logic, 37-38).

37. I thank Shelley Weinberg, Matteo Bonifacio, Kirsten Walsh, Marc Hight, Eric Stencil, and several anonymous referees for helpful comments on previous drafts. I also thank Martin Lenz whose blog criticism of some of the Locke material helped me to clarify my use of the term 'descriptivism' (https://handlingideas.blog/2018/09/15/ all-interpretations-of-ideas-in-locke-are-mistaken-really-a-response-to-kenny-pearce/). A version of this paper was presented at the University College Dublin philosophy colloquium, October 12, 2017. I thank the colloquium participants-especially Ruth Boeker-for helpful discussion. 
SAT Malebranche, Nicolas. (1674-1675) 1997. The Search after Truth. Edited and translated by Thomas M. Lennon and Paul J. Olscamp. Cambridge Texts in the History of Philosophy. Cambridge: Cambridge University Press. French edition: De la Recherche de la Vérité. In Oeuvres Complètes, by Nicolas Malebranche, edited by André Robinet, vol. 1-2. Paris: J. Vrin, 1958-1978.

TFI Arnauld, Antoine. (1683) 1990. On True and False Ideas. Translated by Stephen Gaukroger. Classics of Philosophy and Science. Manchester: Manchester University Press. French edition: Des Vraies et Des Fausses Idées. Edited by Denis Moreau. Paris: J. Vrin, 2011.

\section{References}

Allen, Keith. 2008. "Mechanism, Resemblance and Secondary Qualities: From Descartes to Locke." British Journal for the History of Philosophy 16 (2): 273-291.

- 2010. "Locke and the Nature of Ideas." Archiv für Geschishte der Philosophie 92 (3): 236-255.

Anstey, Peter R. 2009. "The Experimental History of the Understanding from Locke to Sterne." Eighteenth-Century Thought 4:143-169.

2011. John Locke and Natural Philosophy. Oxford: Oxford University Press.

Anstey, Peter R., and John Burrows. 2009. "John Locke, Thomas Sydenham, and the Authorship of Two Medical Essays." Electronic British Library Journal.

Astell, Mary. (1705) 2013. The Christian Religion: As Professed by a Daughter of the Church of England. Edited by Jacqueline Broad. Toronto: Centre for Reformation and Renaissance Studies.

Ayers, Michael. 1991. Locke: Epistemology and Ontology. 2 vols. London and New York: Routledge.

2011. "Primary and Secondary Qualities in Locke's Essay." In Nolan 2011, 136-157.

Bacon, Francis. (1620) 2000. The New Organon. Edited by Lisa Jardine and Michael Silverthorne. Cambridge Texts in the History of Philosophy. Cambridge: Cambridge University Press.

Berkeley, George. (1734) 1992. The Analyst: or, A Discourse Addressed to an Infidel Mathematician. In De Motu and The Analyst: A Modern Edition, with Introductions and Commentary, edited and translated by Douglas M. Jesseph, 159-221. The New Synthese Historical Library. Dordrecht: Kluwer Academic Publishing. 
Berkeley, George. (1735) 1948-1957. A Defence of Free-thinking in Mathematics. In The Works of George Berkeley, Bishop of Cloyne, edited by A. A. Luce and T. E. Jessop, 4:109-141. 9 vols. London: Thomas Nelson and Sons.

Bolton, Martha Brandt. 2004. "Locke on the Semantic and Epistemic Role of Simple Ideas of Sensation." Pacific Philosophical Quarterly 85 (3): 301-321.

Boyle, Robert. (1674) 1991. "About the Excellency and Grounds of the Mechanical Hypothesis." In Selected Philosophical Papers of Robert Boyle, edited by M. A. Stewart, 138-152. Indianapolis: Hackett.

Broad, Jacqueline. 2015. The Philosophy of Mary Astell: An Early Modern Theory of Virtue. Oxford: Oxford University Press.

Browne, Peter. 1697. A Letter in Answer to a Book Entitled Christianity not Mysterious. Dublin: John North.

Clarke, Desmond M., ed. 2008. Philosophical Writings. By George Berkeley. Cambridge Texts in the History of Philosophy. Cambridge: Cambridge University Press.

Connolly, Patrick J. 2018. "Locke and the Methodology of Newton's Principia." Archiv für Geschichte der Philosophie 100 (3): 311-335.

Cook, Monte. 1974. "Arnauld's Alleged Representationalism." Journal of the History of Philosophy 12 (1): 53-62.

1991. "Malebranche Versus Arnauld." Journal of the History of Philosophy 29 (2): 183-199.

1998. "The Ontological Status of Malebranchean Ideas." Journal of the History of Philosophy 36:525-544.

Curley, E. M. 1972. "Locke, Boyle, and the Distinction Between Primary and Secondary Qualities." Philosophical Review 81 (4): 438-464.

Descartes, René. (1641) 1984-1991. Meditations on First Philosophy. In The Philosophical Writings of Descartes, translated by John Cottingham, Robert Stoothoff, Dugald Murdoch, and Anthony Kenny, 2:3-397. Cambridge: Cambridge University Press.

Hacking, Ian. 1974. Why Does Language Matter to Philosophy? Cambridge: Cambridge University Press.

Hankinson, R. J. 1987. "Causes and Empiricism: A Problem in the Interpretation of Later Greek Medical Method." Phronesis 32:329-348.

Harrison, John, and Peter Laslett, eds. 1971. The Library of John Locke. 2nd ed. Oxford: Clarendon Press.

Hight, Marc A. 2001. "Locke's Implicit Ontology of Ideas." British Journal for the History of Philosophy 9 (1): 17-42. 
Hight, Marc A. 2008. Idea and Ontology: An Essay in Early Modern Metaphysics of Ideas. University Park, PA: The Pennsylvania State University Press.

ed. 2013. The Correspondence of George Berkeley. Cambridge: Cambridge University Press.

Hoffman, Paul. 2002. "Direct Realism, Intentionality, and the Objective Being of Ideas." Pacific Philosophical Quarterly 83 (2): 163-179.

Hooke, Robert. 1667. Micrographia: Or Some Physicological Descriptions of Minute Bodies Made by Magnifying Glasses. London: John Martyn.

Jacovides, Michael. 1999. "Locke's Resemblance Theses." Philosophical Review 108 (4): 461-496.

2007. "Locke's Distinctions between Primary and Secondary Qualities." In Newman 2007, 101-129.

- 2017. Locke's Image of the World. Oxford: Oxford University Press.

Jolley, Nicholas. 1990. The Light of the Soul: Theories of Ideas in Leibniz, Malebranche, and Descartes. Oxford: Clarendon Press.

. 2003. "Reason's Dim Candle: Locke's Critique of Enthusiasm." In The Philosophy of John Locke: New Perspectives, edited by Peter R. Anstey, 179-191. London and New York: Routledge.

2007. "Locke on Faith and Reason." In Newman 2007, 436-455.

Kambouchner, Denis. 1995. "Des Vraies et des Fausses Tenébrès: La Connaissance de l'Âme d'après la Controverse avec Malebranche." In Antoine Arnauld: Philosophie du Langage et de la Connaissance, edited by JeanClaude Pariente, 153-190. Histoire de la Philosophie. Paris: J. Vrin.

Law, Edmund, trans. 1732. An Essay on the Origin of Evil. By William King. 2 vols. London: W. Thurlbrurn.

Lennon, Thomas M. 1992. "Malebranche's Argument for Ideas and its Systematic Importance." In Minds, Ideas, and Objects: Essays on the Theory of Representation in Modern Philosophy, edited by Phillip Cummins and Gunther Zoeller, 57-72. North American Kant Society Studies in Philosophy 2. Atascadero, CA: Ridgeview Publishing.

1993. The Battle of the Gods and Giants: The Legacies of Descartes and Gassendi, 1655-1715. Princeton: Princeton University Press.

Locke, John. (1706a) 1823. An Examination of P. Malebranche's Opinion of Seeing All Things in God. In The Works of John Locke, 9:211-255. 10 vols. London: Thomas Tegg.

. (1706b) 1823. Remarks upon some of Mr. Norris's Books, Wherein he Asserts P. Malebranche's Opinion of Seeing All Things in God. In The Works of John Locke, 10:247-259. 10 vols. London: Thomas Tegg. 
Malebranche, Nicolas. (1684) 1958-1978. Reponse De l'Auteur De la Recherche de la Verité, au Livre de Mr. Arnauld, des vrayes 83 des fausses Idées. In Oeuvres Complètes, edited by André Robinet, 6:1-189. Paris: J. Vrin.

. 1958b-1978. Oeuvres Complètes. Edited by André Robinet. Paris: J. Vrin.

McCann, Edwin. 2011. "Locke's Distinction between Primary Primary Qualities and Secondary Primary Qualities." In Nolan 2011, 158-189.

McCracken, Charles J. 1983. Malebranche and British Philosophy. Oxford: Clarendon Press.

Moreau, Denis. 2000. "The Malebranche-Arnauld Debate." In Nadler 2000, 87111.

Nadler, Steven. 1989. Arnauld and the Cartesian Philosophy of Ideas. Studies in intellectual history and the history of philosophy. Princeton: Princeton University Press.

- 1992. Malebranche and Ideas. New York: Oxford University Press.

. 1994. "Malebranche's Theory of Perception." In The Great Arnauld and Some of His Philosophical Correspondents, edited by Elmar J. Kremer, 108128. Toronto: University of Toronto Press.

— ed. 2000. The Cambridge Companion to Malebranche. Cambridge: Cambridge University Press.

Ndiaye, Aloyse Raymond. 1991. La Philosophie d'Antoine Arnauld. Bibliothéque d'Histoire de la Philosophie. Paris: Librairie Philosophique J. Vrin.

Newman, Lex. 2004. "Locke on Sensitive Knowledge and the Veil of PerceptionFour Misconceptions." Pacific Philosophical Quarterly 85 (3): 273-300.

— ed. 2007. The Cambridge Companion to Locke's "Essay Concerning Human Understanding". Cambridge: Cambridge University Press.

- 2009. "Ideas, Pictures, and the Directness of Perception in Descartes and Locke." Philosophy Compass 4 (1): 134-154.

Nolan, Lawrence, ed. 2011. Primary and Secondary Qualities: The Historical and Ongoing Debate. Oxford: Oxford University Press.

Ott, Walter. 2017. Descartes, Malebranche, and the Crisis of Perception. Oxford: Oxford University Press.

Pappas, George S. 2000. Berkeley's Thought. Ithaca, NY: Cornell University Press.

Pearce, Kenneth L. 2016. "Arnauld's Verbal Distinction Between Ideas and Perceptions." History and Philosophy of Logic 37 (4): 375-390. 
Pearce, Kenneth L. 2017. Language and the Structure of Berkeley's World. Oxford: Oxford University Press.

- 2019. "Locke, Arnauld, and Abstract Ideas." British Journal for the History of Philosophy 27 (1): 75-94.

Pessin, Andrew. 2004. "Malebranche on Ideas." Canadian Journal of Philosophy 34 (2): $241-285$.

Plato. 1997. Meno. In Complete Works, edited by John M. Cooper, translated by G.M.A. Grube, 870-897. Indianapolis: Hackett.

Priarolo, Mariangela. 2017. "Universals and Individuals in Malebranche's Philosophy." In The Problem of Universals in Early Modern Philosophy, edited by Stefano Di Bella and Tad Schmaltz, 142-165. Oxford: Oxford University Press.

Pyle, Andrew. 2003. Malebranche. Arguments of the Philosophers. London: Routledge.

— 2013. Locke. Classic Thinkers. Cambridge: Polity Press.

Radner, Daisie. 1976. "Representationalism in Arnauld's Act Theory of Perception." Journal of the History of Philosophy 14 (1): 96-98.

Reid, Thomas. (1785) 2002. Essays on the Intellectual Powers of Man. Edited by Derek R. Brookes. Edinburgh: Edinburgh University Press.

Rogers, G. A. J. 2004. "Locke and the Objects of Perception." Pacific Philosophical Quarterly 85 (3): 245-254.

- 2007. "The Intellectual Setting and Aims of the Essay." In Newman 2007, 7-32.

Schmaltz, Tad M. 2000. "Malebranche on Ideas and the Vision in God." In Nadler 2000, 59-86.

Sergeant, John. 1697. Solid Philosophy Asserted, Against the Fancies of the Ideists: Or, the Method of Science Farther Illustrated. London: Roger Clavil / Abel Roper / Thomas Metcalf.

Sprat, Thomas. 1667. The History of the Royal-Society of London: For the Improving of Natural Knowledge. London: J. Martyn / J. Allestry.

Squadrito, Kathleen M. 1987. "Mary Astell's Critique of Locke's View of Thinking Matter." Journal of the History of Philosophy 25 (3): 433-439.

Stillingfleet, Edward. 1697. A Discourse in Vindication of the Doctrine of the Trinity: With An Answer to the Late Socinian Objections Against it from Scripture, Antiquity and Reason. 2nd ed. London: Henry Mortlock.

Tomida, Yasuhiko. 2005. "Locke's Representationalism Without Veil." British Journal for the History of Philosophy 13 (4): 675-696. 
Van Cleve, James. 2015. "The Sun in the Sky and the Sun in My Mind: Or, Why Arnauld is not Steadfastly a Direct Realist." Appendix H to Problems From Reid. New York: Oxford University Press.

Voltaire. (1734) 2007. Philosophical Letters: Or, Letters Regarding the English Nation. Edited by John Leigh. Translated by Prudence L. Steiner. Indianapolis: Hackett.

Yaffe, Gideon. 2004. "Locke on Ideas of Substance and the Veil of Perception." Pacific Philosophical Quarterly 85 (3): 255-272.

Yolton, John W. 1956. Locke and the Way of Ideas. Oxford: Oxford University Press.

1975. "Ideas and Knowledge in Seventeenth-Century Philosophy." Journal of the History of Philosophy 13 (2): 145-165.

1984. Perceptual Acquaintance From Descartes to Reid. Minneapolis: University of Minnesota Press.

1996. Perception and Reality: A History from Descartes to Kant. Ithaca, NY: Cornell University Press. 